\title{
Incorporation of Poly(Vinyl Alcohol) for The Improved Properties of Hydrothermal Derived Calcium Phosphate Cements
}

\author{
Nurul Nabilah Razali and lis Sopyan* \\ Department of Manufacturing and Materials Engineering, Faculty of Engineering, International Islamic University Malaysia, \\ PO Box 10, 50728 Kuala Lumpur, Malaysia
}

Received October 30, 2017; Accepted March 16, 2018

\begin{abstract}
Calcium phosphate cement (CPC) has been synthesized via a straightforward hydrothermal route. Calcium oxide and ammonium dihydrogen phosphate were used as calcium and phosphate precursors. The precursors were refluxed in distilled water at $90-100{ }^{\circ} \mathrm{C}$ and dried overnight until the calcium phosphate powder was formed. CPC was then produced by mixing the powder and distilled water at the powder-to-liquid $(P / L)$ ratio of 1.5. Poly(vinyl alcohol) (PVA) of 1 to $7 \%(\mathrm{w} / \mathrm{w})$ was added and its effect on physical properties was investigated. It was proved that PVA addition up to $7 \%(w / w)$ has shortened the setting time but decreased the injectability. The PVA free CPC has the initial and final setting times of 71 and $187 \mathrm{~min}$, respectively and the injectability of $99.92 \%$. The compressive strength also increased with the amount of PVA added in CPC. In addition, soaking CPC in Ringer's solution for 7 , 14 and 21 days also gave remarkable effects on cohesion, microstructure and mechanical properties of the cement.
\end{abstract}

Keywords: calcium phosphate cement; hydrothermal method; poly(vinyl alcohol); setting time; injectability

\section{ABSTRAK}

Semen kalsium fosfat (SKF) telah disintesis melalui proses hidrotermal secara langsung. Kalsium oksida dan ammonium dihidrogen fosfat digunakan sebagai kalsium dan fosfat prekursor. Kedua-dua presurkor itu telah direfluks di dalam air suling pada suhu $90-100{ }^{\circ} \mathrm{C}$ dan dikeringkan sehingga terbentuk serbuk kalsium fosfat. SKF kemudian dihasilkan dengan mencampur serbuk dan air suling pada rasio serbuk-ke-cairan 1,5. Poli(vinil alkohol) telah ditambah ke dalam SKF dengan menvariasikan jumlah kepada $1 \mathrm{ke} 7 \%$ (b/b) dan efeknya ini telah diinvestigasi secara sistematis. Dari hasil kajian, jumlah poli(vinil alkohol) 7\% (b/b) terbukti dapat memendekkan waktu pengerasan tetapi melemahkan proses injektabiliti. SKF bebas poli(vinil alkohol) mancatatkan waktu pengerasan awal pada 71 min dan waktu pengerasan akhir pada 187 min, sedangkan presentase injektabiliti adalah 99,92\%. Kekuatan tekan juga menunjukkan peningkatan apabila jumlah poli(vinil alkohol) pada SKF bertambah. Selain itu, proses rendaman SKF di dalam larutan Ringer selama 7, 14 dan 21 hari juga menunjukkan kesan yang luar biasa kepada kohesi, mikrostruktur dan sifat mekanik semen.

Kata Kunci: semen kalsium fosfat; proses hidrotermal; poli(vinil alkohol); waktu pengerasan; injektabiliti

\section{INTRODUCTION}

Development of bone graft is traditionally focused on autografts and allografts which show some limitations such as shortage of bone supplies, pain morbidity, disease transmissions and immunological reactions between patient and donor [1-2]. The use of synthetic bone graft substitutes as bone replacement has dramatically increased over the last few decades to overcome these limitations. Calcium phosphate material is the most extensively used biomaterials as synthetic bone substitutes due to their compatibility with the mineral phase of natural bone. Recently, a number of techniques for development of injectable calcium phosphate cements (CPC) have been attracting much attention from various researchers worldwide.
CPC can be categorized based upon the final product which is brushite (dicalcium hydrogen phosphate, DCPD) and hydroxyapatite (HA). CPC with $\mathrm{HA}$ as the end product have advantages over brushite including high strength, low resorbability and high osteoconductivity [3-4]. Numerous methods of HA powder synthesis have been introduced like hydrothermal [5], sol-gel [6], hydrolysis [7] and solid state reaction [8]. The hydrothermal method is one of the preferable synthesis routes due to the high yield of cement production, controlled morphology and stoichiometric $\mathrm{Ca} / \mathrm{P}$ ratio [9].

CPC is formed by mixing powder and liquid at certain powder-to-liquid $(\mathrm{P} / \mathrm{L})$ ratios until moldable and injectable paste formed [10-11]. Among advantages of CPC are excellent biocompatibility, non-toxicity,

* Corresponding author. Tel : +603-61964592

DOI: $10.22146 /$ ijc.29746 
osteoconductivity and self-hardening ability [12-13]. The handling properties of CPC is significant for bone filler application but CPC has shown a few disadvantages including long setting time, poor injectability and disintegration of cement upon early contact with blood or other bodily fluids $[4,9]$. To overcome these drawbacks, an approach to incorporate polymers into the CPC formulation, either in the liquid or solid phase has been developed. This strategy is one preferred option to improve the CPC properties in terms of injectability, setting time, cohesion and cell response [3,14]. It is to be hoped that high performance calcium phosphate cement can be obtained to respond recent increasing demand of bone graft substitutes.

Polymeric additives that have been widely used include poly(lactic-co-glycolic acid) (PLGA), poly(ethylene glycol) (PEG), poly(vinyl alcohol) (PVA), poly(acrylic acid), chitosan, polyamides and alginate [1517]. PVA is one of the hydrophilic biocompatible polymer that has been investigated for its possibility in numerous applications. Composites of PVA with carbonized coconut shell [18] and pineapple leaf derived cellulose fibers for high performance packaging materials [19] have been developed recently. In biomedical engineering field, PVA has been evaluated for hydrogel use [20], degradable film composite with fish collagen [21], polymeric membrane with chitosan and citric acid for hemodialysis application [22] and use as a binder for calcium phosphate cement [23]. Its high hydrophilicity and fast swelling when absorbing water are among the main reasons of using PVA to enhance performance of CPC [24]. The aim of the present work is to develop an injectable CPC with incorporation of PVA for better selfsetting control and cohesion of cement.

\section{EXPERIMENTAL SECTION}

\section{Materials}

Calcium oxide, $\mathrm{CaO}$ (Bendosen Laboratory Chemicals) and ammonium dihydrogen phosphate, $\mathrm{NH}_{4} \mathrm{H}_{2} \mathrm{HPO}_{4}$ (Friendmann Schmidt Chemical) were used to produce hydroxyapatite powder. The hydroxyapatite was used as the solid phase, while distilled water as the liquid phase and PVA (R\&M Chemicals, MW 144K, 87$89 \%$ hydrolyzed) as the binder.

\section{Instrumentation}

The instruments used were a siever (Retsch ZM 200), a Field Emission Scanning Electron Microscope (JEOL JSM 6700F), Gillmore apparatus and Lloyd Universal Testing Machine, LR $10 \mathrm{~K}+$.

\section{Procedure}

\section{Synthesis of powder}

The preparation of calcium phosphate cement (CPC) was conducted by mixing the hydrothermal derived hydroxyapatite powder and distilled water. The hydrothermal synthesis of HA powder was reported elsewhere [25]. The chemical reaction to synthesize $\mathrm{HA}$ powder is as follows:

$5 \mathrm{CaO}+3 \mathrm{NH}_{4} \mathrm{H}_{2} \mathrm{PO}_{4} \rightarrow \mathrm{Ca}_{5}\left(\mathrm{PO}_{4}\right)_{3} \mathrm{OH}+3 \mathrm{NH}_{4} \mathrm{OH}+\mathrm{H}_{2} \mathrm{O}$

On the basis of Equation (1), the stoichiometric weight of calcium oxide ( $\mathrm{CaO})$ and ammonium dihydrogen phosphate $\left(\mathrm{NH}_{4} \mathrm{H}_{2} \mathrm{HPO}_{4}\right)$ were used to produce hydroxyapatite based on $1.67 \mathrm{Ca} / \mathrm{P}$ ratio. The synthesized $\mathrm{HA}$ was then dried overnight at $85^{\circ} \mathrm{C}$ in an oven. The dried powder produced was then crushed and sieved with a siever.

\section{Preparation of calcium phosphate cement}

The preparation of CPC was done by homogenously mixing the powder and liquid phases for $3 \mathrm{~min}$ at the $(\mathrm{P} / \mathrm{L})$ ratio of 1.5. PVA content added was varied from 1 to $7 \%(\mathrm{w} / \mathrm{w})$ to the CPC. The CPC paste was then filled into a Teflon (PTFE) mould of $10 \mathrm{~mm}$ diameter and $15 \mathrm{~mm}$ height by hand spatulation.

\section{Cement characterization}

Morphological analysis on the powder was done using a JEOL JSM 6700F. Sputter coating was applied using gold for $50 \mathrm{sec}$ with a deposition current of 60 $\mathrm{mA}$. Different acceleration condition and voltage were applied to observe the microstructure of CPC with and without PVA.

The injectability test was performed through extrusion method by filling the $5 \mathrm{~mL}$ non-needle syringe with the paste. The Lloyd Universal Testing Machine, LR $10 \mathrm{~K}+$ model was used to measure the injectability of paste under compression mode with a maximum load of $300 \mathrm{~N}$ and a crosshead speed of $50 \mathrm{~mm} / \mathrm{min}$. The evolution of the extrusion force $(\mathrm{N})$ against the extrusion time (sec) was recorded to determine the force of the syringe. The injectability test of CPC without PVA and CPC with the addition of 1 to $3 \%$ (w/w) PVA was then compared.

The setting times of CPC with PVA concentrations of $1,2,3,5,6$ and $7 \%(\mathrm{w} / \mathrm{w})$ were measured using Gillmore method. The CPC paste was homogenously mixed before moulded in a polyethylene mould. The initial and final setting times were performed by applying the thick and thin Gillmore needles in vertical position on the cement surface until no visible indentation formed.

The compression strength was performed by utilizing the Lloyd Universal Testing Machine, LR $10 \mathrm{~K}+$ model at $1 \mathrm{~mm} / \mathrm{min}$ crosshead rate for all the samples 
of CPC with the dimension of $10 \mathrm{~mm}$ diameter $\times 15 \mathrm{~mm}$ length. Before subjected to the compression test, the cements were moulded in a Teflon mould and left dried overnight.

\section{RESULT AND DISCUSSION}

\section{Injectability}

Fig. 1 shows the time taken of CPC to extrude the whole paste from the syringe using Universal Testing Machine. CPC without PVA performed good injectability and the time taken for paste extrusion is $40 \mathrm{sec}$, in which $99.92 \%$ of the cement has been extruded proving an excellent injectability. After 2\% (w/w) PVA was added, the paste shows poor injectability and reduced the extrusion time of $33 \mathrm{sec}$ due to the absorption of water molecules by PVA which leads to more viscous paste. From Fig. 2(a) and 2(b), both the PVA free CPC and CPC with $1 \%(\mathrm{w} / \mathrm{w})$ PVA were able to extrude the whole paste from the syringe. However, Fig. 2(c) shows that CPC with $2 \%(\mathrm{w} / \mathrm{w})$ PVA addition has little paste remain in the syringe which represents poor injectability. None of paste can be injected after $3 \%$ (w/w) PVA was added as shown in Fig. 2(d). Overall, the decrease in injectability was observed after the addition of more PVA amount to the CPC.

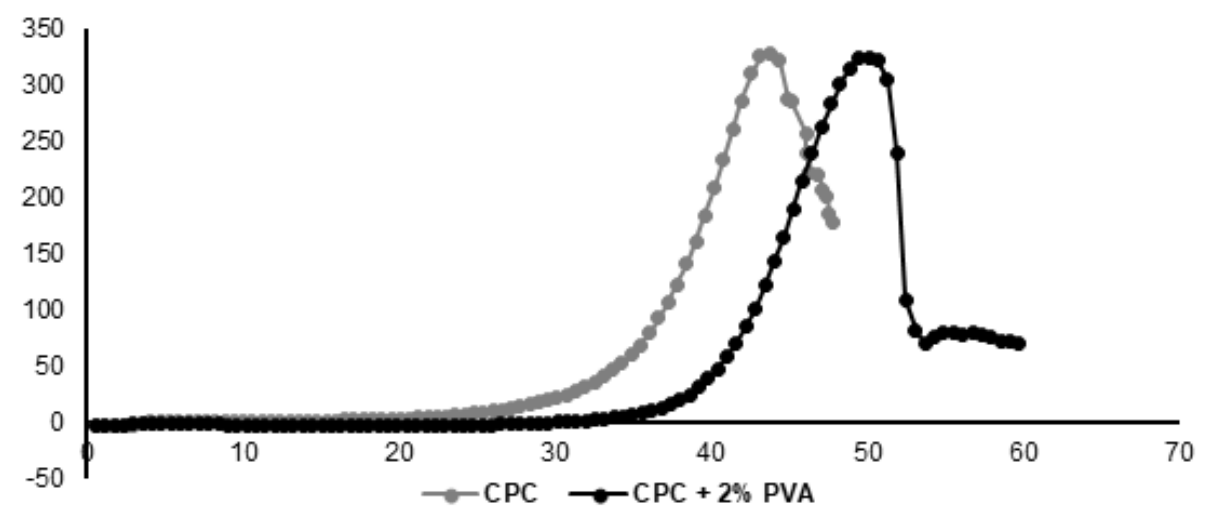

Fig 1. Injectability of PVA free CPC and CPC with 2 wt $\%$ PVA

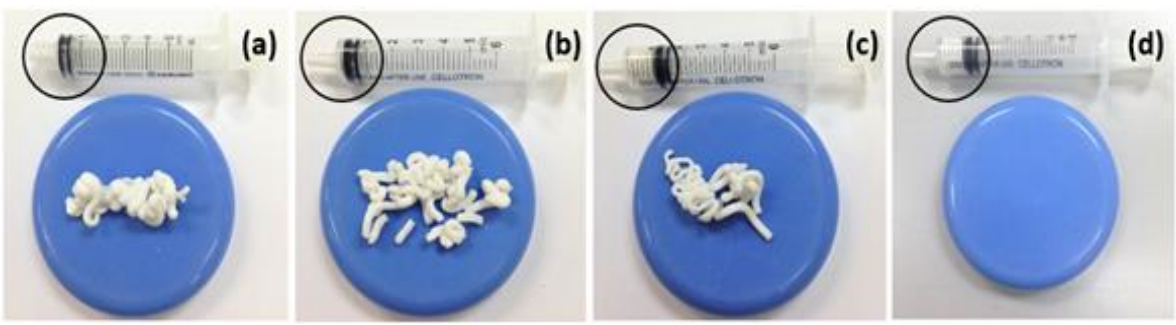

Fig 2. Moldable forms of CPC with variation in PVA concentrations: (a) $0 w t \%$ (b) 1 wt\% (c) $2 w t \%$ and (d) $3 w t \%$

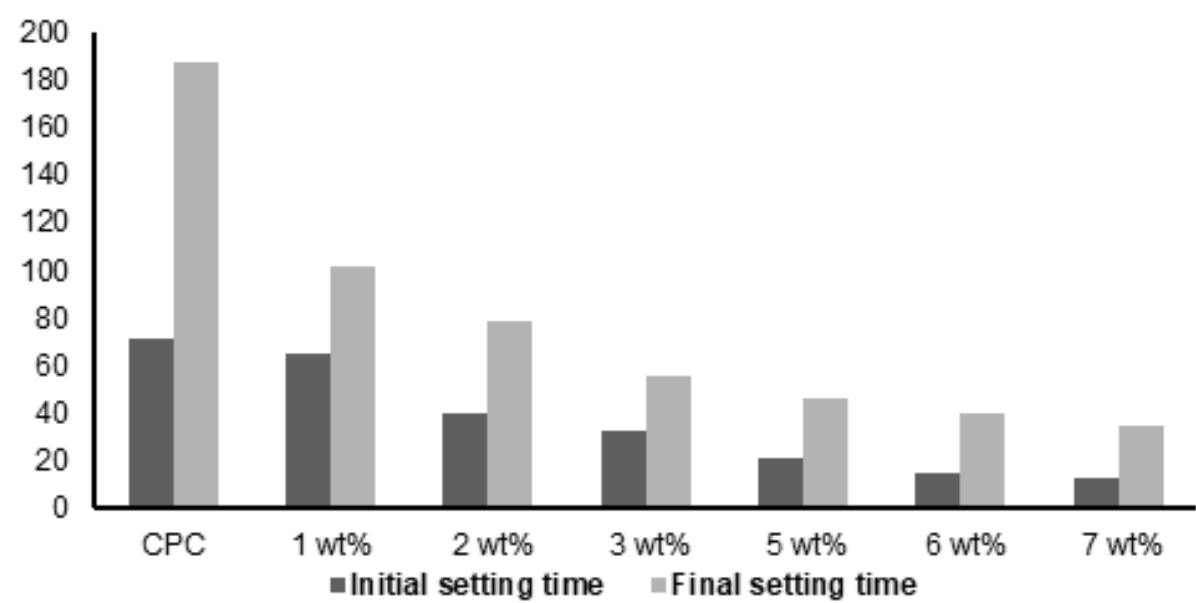

Fig 3. Initial and final setting times of $C P C$ at various PVA concentrations 


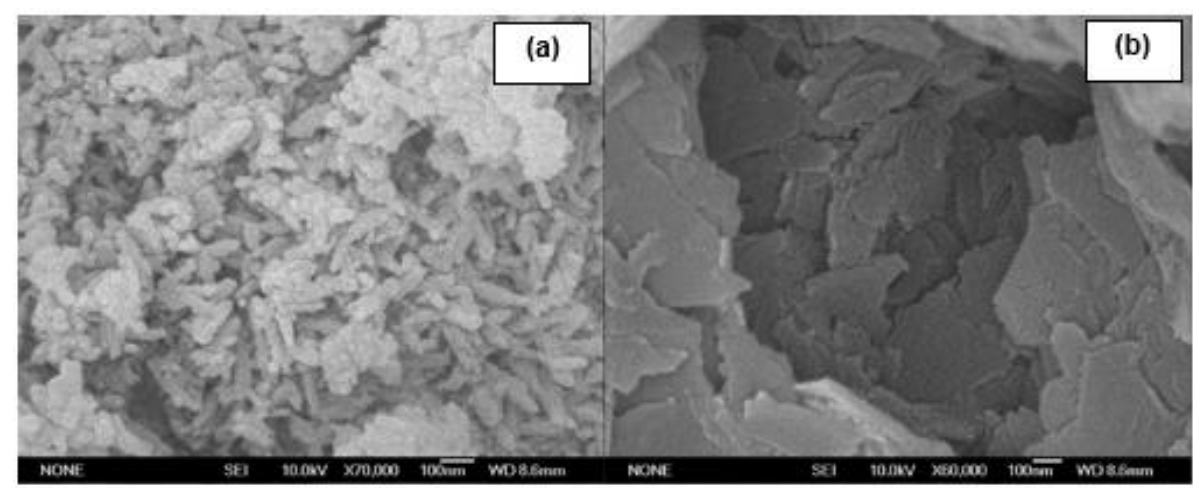

Fig 4. Microstructure of CPC particles: (a) PVA free CPC (b) CPC with 2 wt\% PVA

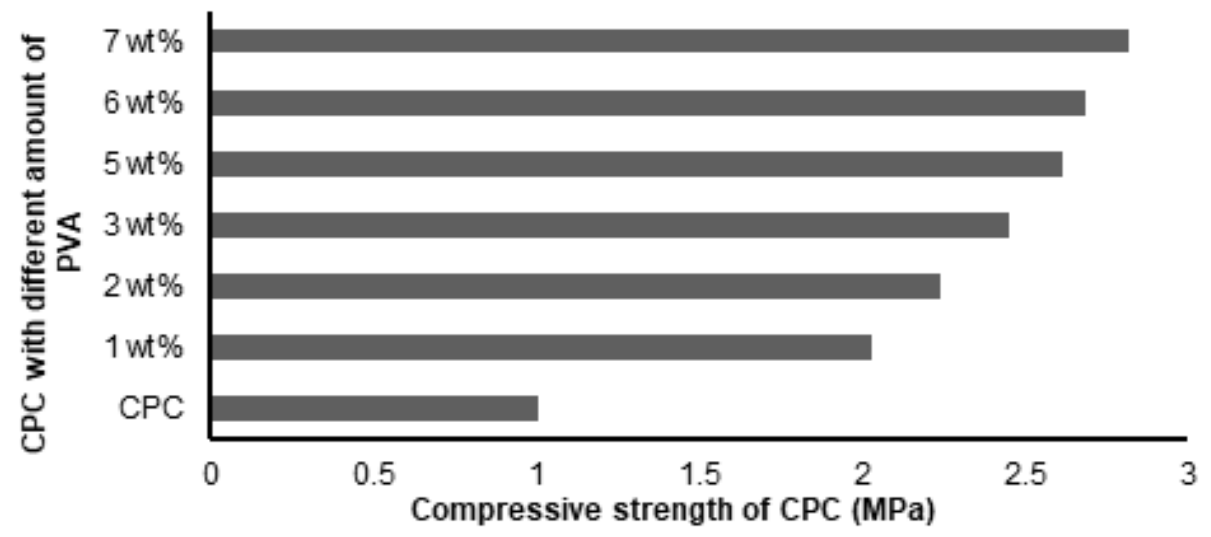

Fig 5. Compressive strength of CPC with the variation in PVA concentrations

\section{Setting Time}

Fig. 3 represents the initial and final setting times of CPC without and with PVA. The initial setting time of CPC without PVA is $71 \mathrm{~min}$, and decreased to 65,40 , $33,21,15$ and 13 min, respectively when PVA with the concentrations of $1,2,3,5,6$ and $7 \%(\mathrm{w} / \mathrm{w})$ were added. While, the final setting time of CPC without PVA was 187 $\mathrm{min}$, and declined to $102,79,56,46,40$ and $35 \mathrm{~min}$ when PVA were added. The difference in the setting times were related to injectability test result discussed above. The incorporation of CPC to PVA was able to increase the viscosity of cement, which simultaneously increased the rate of self-hardening and reduced the injectability of cement. This result is not in agreement to a previous report [24] which claimed that PVA addition with the presence of glycerol to CPC increased the setting time, probably caused by the high viscosity of glycerol.

\section{Microstructure Analysis}

Fig. 4 presents the results of microstructure analysis using FESEM. In Fig. 4(a), the particles were in spherical and flakes shapes with nanosize particles of $100 \mathrm{~nm}$ long which represents HA powder. The agglomerated particles of needle like microstructure also formed. The microstructure of CPC with addition of $2 \%(w / w)$ PVA is shown in Fig. 4(b). The HA particles were no longer visible because the particles surface were fully covered by PVA.

\section{Compressive Strength}

The PVA addition has shown an improvement to the compressive strength of the CPC. Fig. 5 shows the results of compressive strength of CPC without and when PVA was added with the concentrations of 1,2 , $3,5,6$ and $7 \%(\mathrm{w} / \mathrm{w})$. The lowest compressive strength was achieved by CPC without PVA (1.01 MPa) and the highest compressive strength was by CPC with $7 \%$ $(\mathrm{w} / \mathrm{w})$ of PVA (2.86 MPa). An increase in compressive strength was observed with the increased amount of PVA. This trend is in agreement with setting times results shown in Fig. 3. An increase in rate of selfsetting of CPC tends to increase the mechanical strength of CPC due to the high viscosity of PVA. 


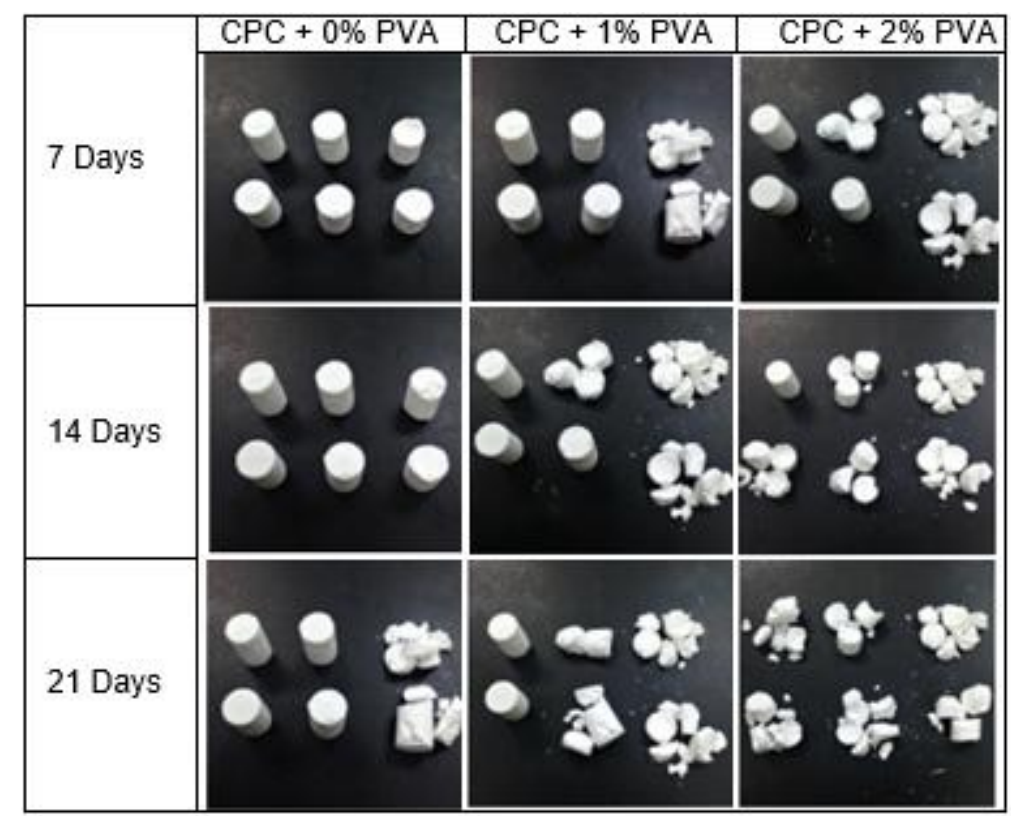

Fig 6. Cohesiveness of CPC after soaking in Ringer's solution for 7, 14 and 21 days

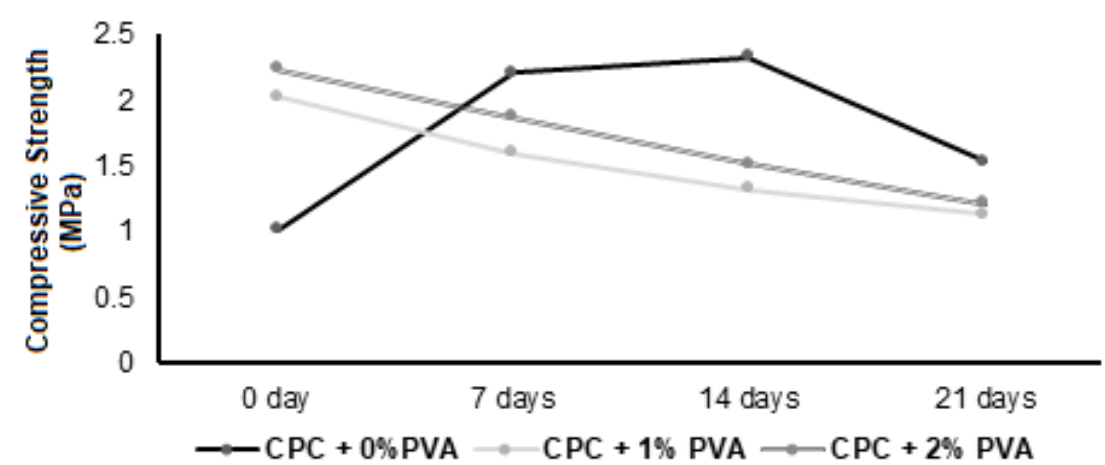

Fig 7. Compressive strength of CPC after soaking in Ringer's solution for 7,14 and 21 days

\section{Cement Integrity}

\section{Cohesiveness}

Incorporation of PVA to the CPC has shown some effects on the integrity, microstructure and compressive strength of CPC after soaking in Ringer's solution for 0 , 7, 14 and 21 days. Fig. 6 shows the integrity of cements after 1 and $2 \%(w / w)$ of PVA were added to the CPC at different soaking times: $0,7,14$ and 21 days. CPC without PVA shows high integrity and cohesiveness after 14 days soaking but disintegrates after 21 days soaking in Ringer's solution. However, after PVA was added to the CPC, the cements tend to decrease its cohesiveness and increase its brittleness with increasing the time of soaking in Ringer's solution. The result differed from a report which claimed that PVA with the presence of glycerol gives high anti-washout ability to CPC, probably caused by the high viscosity of glycerol [24]. The hydrophilicity of PVA is presumed to be the main reason of disintegration of cement after soaking in the Ringer's solution.

\section{Microstructure analysis}

The disintegration and reduction in cohesiveness of $\mathrm{CPC}$ was in agreement with the compressive strength test and microstructure analysis using FESEM. The compressive strength of CPC without PVA increased from 1.01 MPa to 2.21 and $2.33 \mathrm{MPa}$ after 7 and 14 days soaking, respectively, in Ringer's solution as Fig. 7 shows. Mohammadi et al. [26] also reported that CPC tends to increase compressive strength after 14 days soaking in Ringer's solution. After 7 and 14 days soaking, the compressive strength of CPC shows improvement because of growth and formation of tiny apatite phase crystals [27]. However, CPC without PVA has reduced compressive strength to $1.53 \mathrm{MPa}$ after 21 days soaking in Ringer's solution. Meanwhile, after 1 and 2\% (w/w) of PVA were added, 


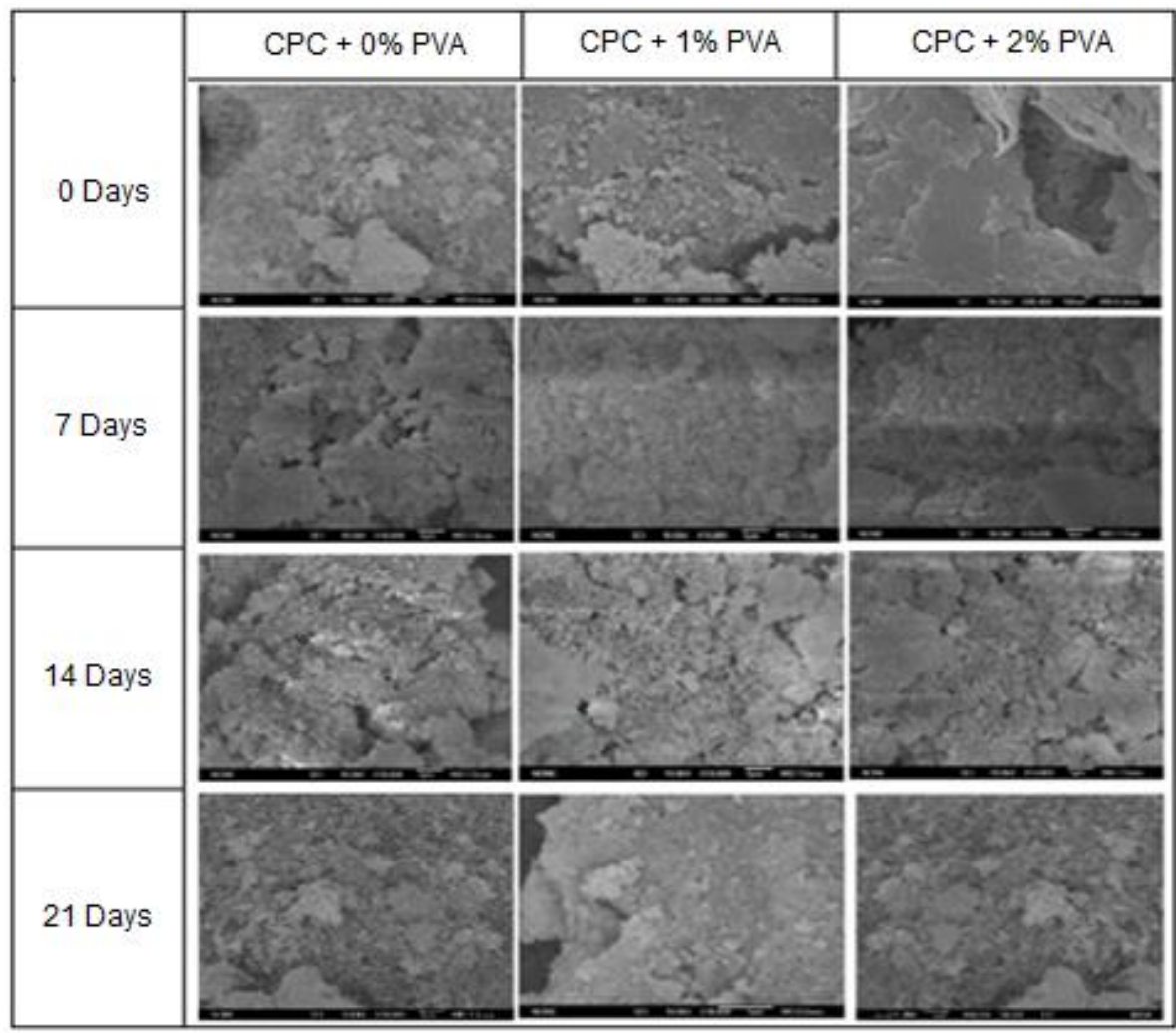

Fig 8. FESEM images of CPC surfaces after soaking in Ringer's solution for 7, 14 and 21 days

the compressive strength decreased eventually from $2.03 \mathrm{MPa}$ to $1.13 \mathrm{MPa}$ and from $2.24 \mathrm{MPa}$ to $1.21 \mathrm{MPa}$, respectively after 21 days soaking in Ringer's solution. Cement with PVA addition has started to show some disintegration from the first day of soaking in Ringer's solution.

\section{Compressive strength}

The results of microstructure analysis using FESEM was shown in Fig. 8. Without PVA addition, HA particles have increased its agglomeration between the first day and 14 days soaking in Ringer's solution. This was supported by the compressive strength result where the strength of CPC without PVA tends to increase up to 14 days soaking in Ringer's solution. Meanwhile, after 1 and $2 \%(\mathrm{w} / \mathrm{w})$ of PVA were added, PVA particles that cover the HA particles have dissolved in Ringer's solution and fine spherical particles which represents the hydroxyapatite particles were then appeared. The hydrophilic behavior of PVA has increased the solubility of CPC in Ringer's solution and presumed to be the main reason of disintegration of CPC.

\section{CONCLUSION}

Poly(vinyl alcohol) was incorporated into hydrothermal derived calcium phosphate cement and its physical properties was investigated. The PVA free CPC shows the initial and final setting times of 71 and $187 \mathrm{~min}$, respectively, at $99.92 \%$ injectability and were shortened from 71 to $13 \mathrm{~min}$ and 187 to $35 \mathrm{~min}$ after the addition of $7 \%(\mathrm{w} / \mathrm{w})$ PVA. Its compressive strength increased with the PVA amount which revealed much better ductility of CPC. The compressive strength is $1.01 \mathrm{MPa}$ for CPC without PVA and increased to 2.86 $\mathrm{MPa}$ after $7 \%(\mathrm{w} / \mathrm{w})$ of PVA addition. CPC with $2 \%$ (w/w) PVA shows poor injectability compared to pure CPC where some portion of the paste remained in syringe after extrusion. While, CPC with $3 \%$ (w/w) PVA was unable to extrude the whole paste from the syringe indicate the paste has harden completely in syringe before injected. The cohesiveness test using the Ringer's solution revealed that the increase in PVA concentrations has lowered the anti-washout ability and the compressive strength of the CPC with the increasing time of soaking in Ringer's solution. Without PVA, CPC shows high integrity but after 21 days stored in Ringer's solution, the cement washed-out and its compressive strength decreased. Overall, PVA was proven to be a suitable polymeric additive for the hydrothermal derived $\mathrm{CPC}$, which help enhancing the compressive strength and shortening the setting time of the CPC. 


\section{ACKNOWLEDGEMENT}

This work was financially supported by Ministry of Higher Education (MOHE) through Fundamental Research Grant Scheme (FRGS) with the project ID of FRGS15-246-0487.

\section{REFERENCES}

[1] Banwart, J.C., Asher, M.A., and Hassanein, R.S., 1995, Iliac crest bone graft harvest donor site morbidity: A statistical evaluation, Spine, 20 (9), 1055-1060.

[2] Sarkar, M.R., Wachter, N., Patka, P., and Kinzl, L., 2001, First histological observations on the incorporation of a novel calcium phosphate bone substitute material in human cancellous bone, J. Biomed. Mater. Res., 58 (3), 329-334.

[3] Bohner, M., Merkle, H.P., Landuyt, P.V., Trophardy, G., and Lemaitre, J., 2000, Effect of several additives and their admixtures on the physicochemical properties of a calcium phosphate cement, J. Mater. Sci. - Mater. Med., 11 (2), 111-116.

[4] Wang, X., Ma, J., Wang, Y., and He, B., 2001, Structural characterization of phosphorylated chitosan and their applications as elective additives of calcium phosphate cements, Biomaterials, 22 (16), 2247-2255.

[5] Zhang, C., Yang, J., Quan, Z., Yang, P., Li, C., Hou, Z., and Lin, J., 2009, Hydroxyapatite nano- and microcrystals with multiform morphologies: Controllable synthesis and luminescence properties, Cryst. Growth Des., 9 (6), 2725-2733.

[6] Bezzi, G., Celotti, G., Landi, E., La Toreetta, T.M.G., Sopyan, I., and Tampieri, A., 2003, A novel sol-gel technique for hydroxyapatite preparation, Mater. Chem. Phys., 78 (3), 816-824.

[7] Monma, H., and Kamiya, T., 1987, Preparation of hydroxyapatite by the hydrolysis of brushite, J. Mater. Sci., 22 (12), 4247-4250.

[8] Pramanik, S., Agarwal, A.K., Rai, K.N., and Garg, A., 2007, Development of high strength hydroxyapatite by solid-state sintering process, Ceram. Int., 33 (3), 419-426.

[9] Liu, J., Ye, X., Wang, H., Zhu, M., Wang, B., and Yan, $\mathrm{H} ., 2003$, The Influence of $\mathrm{pH}$ and temperature on the morphology of hydroxyapatite synthesized by hydrothermal method, Ceram. Int., 29 (6), 629-633.

[10] Zhang, J., Liu, W., Gauthier, O., Sourice, S., Pilet, P., Rethore, G., Khairoun, K., Bouler, J.M., Tancret, F., and Wiess, P., 2014, Calcium phosphate cements for bone substitution: chemistry, handling and mechanical properties, Acta Biomater., 10 (3), 1035-1049.
[11] Li, L., Peng, X., Qin, Y., Wang, R., Tang, J., Cui, X., Wang, T., Liu, W., Oan, H., and Li, B., 2017, Acceleration of bone regeneration by activating wnt/ $\beta$-catenin signalling pathway via lithium released from lithium chloride/calcium phosphate cement in osteoporosis, Sci. Rep., 7, 45204, 1-12.

[12] Lopez-Heredia, M.A., Sariibrahimoglu, K., Yang, W., Bohner, M., Yamashita, D., Kunstar, A., van Apeldoorn, A.A., Bronkhorst, E.M., Félix Lanao, R.P., Leeuwenburgh, S.C., Itatani, K., Yang, F., Salmon, P., Wolke, J.G., and Jansen, J.A., 2012, Influence of the pore generator on the evolution of the mechanical properties and the porosity and interconnectivity of a calcium phosphate cement, Acta Biomater., 8 (1), 404-414.

[13] Sariibrahimoglu, K., Leeuwenburgh, S.C.G., Wolke, J.G.C., Yubao, L., and Jansen, J.A., 2012, Effect of calcium carbonate on hardening, physicochemical properties, and in vitro degradation of injectable calcium phosphate cements, J. Biomed. Mater. Res. PartA, 100(3), 712-719.

[14] Perez, R.A., Kim, H.W., and Ginebra, M.P., 2012, Polymeric additives to enhance the functional properties of calcium phosphate cements, $J$. Tissue Eng., 3 (1), 1-21.

[15] Engstrand, J., Persson, C., and Engqvist, H., 2013, Influence of polymer addition on the mechanical properties of a premixed calcium phosphate cement, Biomatter, 3 (4), e27249, 1-6.

[16] Renno, A.C., Nejadnik, M.R., van de Watering, F.C., Crovace, M.C., Zanotto, E.D., Hoefnagels, J.P., Wolke, J.G., Jansen, J.A., and van den Beucken, J.J., 2013, Incorporation of bioactive glass in calcium phosphate cement: material characterization and in vitro degradation, $J$. Biomed. Mater. Res. Part A, 101 (8), 2365-2373.

[17] Khashaba, R.M., Moussa, M.M., Mettenburg, D.J., Rueggeberg, F.A., Chutkan, N.B., and Borke, J.L., 2010, Polymeric-calcium phosphate cement composites-materials properties: in vitro and in vivo investigations, Int. J. Biomater., 2010, 691452, 1-14.

[18] Rampe, M.J., Setiaji, B., Trisunaryanti, W., and Triyono, 2011, Fabrication and characterization of carbon composite from coconut shell carbon, Indones. J. Chem., 11 (2), 124-130.

[19] Wahyuningsih, K., Iriani, E.S., and Fahma, F., 2016, Utilization of cellulose from pineapple leaf fibers as nanofiller in polyvinyl alcohol-based film, Indones. J. Chem., 16 (2), 181-189.

[20] Erizal and Rahayu, C., 2009, Thermo-responsive hydrogel of polyvinyl alcohol (PVA)-co-N-isopropyl acrylamide (NIPAAM) prepared by $\mathrm{y}$ radiation as a 
matrix pumping/on-off system, Indones. J. Chem., 9 (1), 19-27.

[21] Perkasa, D.P., Erizal, and Abbas, B., 2013, Polymeric biomaterials film based on poly(vinyl alcohol) and fish scale collagen by repetitive freezethaw cycles followed by gamma irradiation, Indones. J. Chem., 13 (3), 221-228.

[22] Lusiana, R.A., Siswanta, D., Mudasir, and Hayashita, T., 2013. The influence of PVA.cl.citric acid/chitosan membrane hydrophilicity on the transport of creatinine and urea, Indones. J. Chem., 13 (3), 262-270.

[23] Li, C., Gao, L., Chen, F., and Liu, C., 2015, Fabrication of mesoporous calcium silicate/calcium phosphate cement scaffolds with high mechanical strength by freeform fabrication system with microdroplet jetting, J. Mater. Sci., 50 (22), 7182-7191.

[24] Rajzer, I., Castano, O., Engel, E., and Planell, J.A., 2010, Injectable and fast resorbable calcium phosphate cement for body-setting bone grafts, $J$. Mater. Sci. - Mater. Med., 21 (7), 2049-2056.

[25] Alqap, A.S.F., and Sopyan, I., 2009, Low temperature hydrothermal synthesis of calcium phosphate ceramics: effect of excess Ca precursor on phase behavior, Indian. J. Chem., Sect. A, 48A (11), 1492-1500.

[26] Mohammadi, M., Herasaki, S., and Ardakani, M.H., 2012, Effect of adding nano-silicon carbide on mechanical properties and hydroxyapatite formation in calcium phosphate cements, Proceedings of ICBME 2012, 20-21 December, Tehran, Iran.

[27] Müller, L., and Müller, F.A., 2006, Preparation of SBF with different $\mathrm{HCO}_{3}{ }^{-}$content and its influence on the composition of biomimetic apatites, Acta Biomater., 2(2), 181-189. 